\title{
In situ hybridisation of albumin mRNA in normal liver and hepatocellular carcinoma with a digoxigenin labelled oligonucleotide probe
}

\author{
G I Murray, P J Paterson, S W B Ewen, W T Melvin
}

\begin{abstract}
Aims: To study the localisation and distribution of albumin mRNA in normal liver and hepatocellular carcinoma by in situ hybridisation with an oligonucleotide probe.

Methods: A 51 base oligonucleotide was synthesised from a sequence at the 5 end of the human albumin gene and the probe was labelled at its $3^{\prime}$ end with digoxigenin 11-dUTP. Formalin fixed, wax embedded sections of liver biopsy specimens were used to study the localisation and distribution of albumin mRNA. After in situ hybridisation the bound probe was visualised using a digoxigenin antibody conjugated with alkaline phosphatase.

Results: In normal liver albumin mRNA was detected in hepatocytes and no positive signal was observed in biliary epithelium, vascular endothelium, or Kupffer cells. In $75 \%(9 / 12)$ of the hepatocellular carcinomas studied a positive hybridisation signal was observed in tumour cells.

Conclusions: Albumin mRNA can be detected in sections of formalin fixed, wax embedded liver, a digoxigenin labelled probe is ideally suited for in situ hybridisation of liver because there is no background from the detection system. The identification of albumin mRNA may be a useful marker of hepatocellular carcinoma, and the demonstration of albumin mRNA by in situ hybridisation overcomes the potential background problem associated with albumin immunohistochemistry.
\end{abstract}

Department of Pathology University of Aberdeen, Fosterhill, Aberdeen AB9 2ZD G I Murray P J Paterson $S$ W B Ewen

Department of Molecular and Cell Biology W T Melvin

Correspondence to: Dr G I Murray

Accepted for publication 4 July 1991
In situ hybridisation is a technique that is increasingly being used to study gene expression because it permits the localisation of specific DNA and RNA sequences in tissue sections and cells. ${ }^{1}$ Probes for in situ hybridisation may be cloned sequences of DNA, or RNA, or synthetic oligonucleotides, and the probes may be labelled with nucleotides containing radioactive isotopes of sulphur $\left({ }^{35} \mathrm{~S}\right)$, phosphorus $\left({ }^{32} \mathrm{P}\right)$, or tritium $\left({ }^{3} \mathrm{H}\right)$, or a variety of non-radioactive reporter molecules.

At present the most widely used nonradioactive reporter molecule is biotin, but several tissues, notably liver and kidney, con- tain a high concentration of endogenous biotin and this causes serious problems of background staining. Other reporter molecules include fluorescein, ${ }^{2}$ bromodeoxyuridine, ${ }^{3}$ and digoxigenin. ${ }^{45}$ Digoxigenin has recently been introduced as a reporter molecule for in situ hybridisation and its use does not seem to be associated with intrusive background staining of tissues. Chemical modification (sulphonation) of cytidine residues in DNA probes and immunological detection of the sulphonated probes have also been used. ${ }^{6}$

In situ hybridisation is becoming increasingly important in pathology, and the detection of viral DNA sequences ${ }^{7}$ in tissue sections using non-radioactive labelled probes is widely reported. There have been fewer studies of the detection of specific mRNA sequences using non-radioactive labelled probes. Messenger RNA species which have been localised include chromogranin mRNA, immunoglobulin light chain mRNA, $^{9}$ and interleukin-5 mRNA. ${ }^{10}$ In all of these examples in situ hybridisation was performed using oligonucleotide probes.

Oligonucleotide probes are ideally suited for in situ hybridisation ${ }^{11}$ as their relatively small size facilitates penetration into tissue sections. They are also easily synthesised and stored, and they can also be used to differentiate closely related nucleic acid sequences. We studied the localisation of albumin mRNA in normal liver and hepatocellular carcinoma using a 51 base oligonucleotide that was labelled at its $3^{\prime}$ end with digoxigenin.

\section{Methods}

A 51 base oligonucleotide probe complementary to a sequence at the $5^{\prime}$ end of the coding region of the human albumin gene ${ }^{12}$ was synthesised (Oswel DNA Service, Edinburgh) and was purified by high pressure liquid chromatography before use. The probe sequence was 5'-ATA AGC CGA GCT AAA GAG AAA AAG AAG GGA AAT AAA GGT TAC CCA CTT CAT-3'. This oligonucleotide probe sequence has been used to detect albumin mRNA in northern blots of human liver mRNA. ${ }^{13}$

\section{PROBE LABELLING}

The oligonucleotide probe was labelled at its $3^{\prime}$ end with digoxigenin 11-dUTP (Boehringer 
Mannheim UK, Lewes, East Sussex). The labelling reaction consisted of $3 \mu \mathrm{l}$ probe (100 pmol), $10 \mu 15 \times$ tailing buffer (Boehringer), 20 $\mu \mathrm{l}$ cobalt chloride ( $5 \mathrm{mmol} / \mathrm{l}), 3.5 \mu \mathrm{l}$ dATP $(2.5$ $\mathrm{mmol} / \mathrm{l}$, Boehringer), $1 \mu \mathrm{l}$ digoxigenin $11-$ dUTP ( $1 \mathrm{mmol} / \mathrm{l}$, Boehringer), $1 \mu \mathrm{l}$ terminal transferase (55 U/ $/ \mu \mathrm{l}$, Boehringer) and $11.5 \mu \mathrm{l}$ sterile distilled water. The reaction mixture was incubated for $60-90$ minutes at $37^{\circ} \mathrm{C}$ and then the labelling reaction was stopped by the addition of $12.5 \mu \mathrm{l}$ of ice-cold EDTA $(0.2$ $\mathrm{mol} / \mathrm{l}, \mathrm{pH} 8 \cdot 0$ ). The probe was then purified by acetate ethanol precipitation.

\section{PROBE PURIFICATION}

Sterile distilled water $(120 \mu \mathrm{l})$ was added to $30 \mu \mathrm{l}$ of labelling reaction mixture, followed by $15 \mu \mathrm{l}$ of $4.5 \mathrm{M}$ sodium acetate $(\mathrm{pH} 6.0)$ and $1.5 \mu \mathrm{l}$ of a $20 \mathrm{mg} / \mathrm{ml}$ glycogen solution (Boehringer). Then $450 \mu \mathrm{l}$ of ice-cold ethanol was added and the solution chilled in a deep freeze $\left(-25^{\circ} \mathrm{C}\right)$ overnight. The solution was then centrifuged for five minutes at $12000 \times \mathrm{g}$, the supernatant discarded, and the pellet washed by adding $300 \mu \mathrm{l}$ of ice-cold $70 \%$ ethanol and centrifuged again for a further five minutes. The supernatant was discarded and the purified probe lyophilised. Finally, the probe was resuspended in $10 \mu \mathrm{l}$ sterile distilled water and stored at $-20^{\circ} \mathrm{C}$.

\section{TISSUE}

Needle and wedge biopsy specimens of liver (eight normal and 12 hepatocellular carcinoma) and resected specimens of pancreas submitted to the Department of Pathology, University of Aberdeen for histopathological examination were used in this study. Biopsy specimens were immersion fixed in $10 \%$ neutral buffered formalin at room temperature for 24 hours and then processed to paraffin wax. Sections ( $5 \mu \mathrm{m}$ thick) were cut and mounted on slides coated with poly L-lysine (Sigma Chemical, Poole, Dorset) and air dried at room temperature for 24 hours before use.

\section{IN SITU HYBRIDISATION}

Sections of liver or pancreas were dewaxed in clean xylol for five minutes and then rehydrated in $100 \%$ alcohol and $95 \%$ alcohol for successive five minute periods. The slides were washed in sterile distilled water for two five minute periods and the sections then digested with proteinase $\mathrm{K}$ (protease type XI, Sigma, 10 $\mu \mathrm{l} / \mathrm{ml}$ in TRIS-HCl buffer, $\mathrm{pH} 7 \cdot 6$, containing $50 \mathrm{mM}$ EDTA) for up to 75 minutes at $37^{\circ} \mathrm{C}$. Enzyme digestion was stopped by washing the slides in sterile distilled water followed by $4 \times$ SSC (SSC $=$ sodium chloride, sodium citrate: $1 \times \mathrm{SSC}=0.15 \mathrm{M}$ sodium chloride $8.7 \mathrm{~g} / \mathrm{l}$, $0.015 \mathrm{M}, 0.015 \mathrm{M}$ trisodium citrate $4.4 \mathrm{~g} / \mathrm{l}$, $\mathrm{pH} \mathrm{7.0).}$

Non-specific probe binding was blocked by prehybridising the sections with hybridisation buffer $(5 \times$ SSC, $5 \mathrm{mg} / \mathrm{ml}$ sodium pyrophosphate, Denhardt's solution (0.02\% Ficoll, $0.02 \%$ bovine serum albumin, $0.02 \%$ polyvinyl pyrrolidone), $100 \mu \mathrm{g} / \mathrm{ml}$ denatured DNA (Sigma), and $125 \mu \mathrm{g} / \mathrm{ml}$ RNA (Sigma). Labelled probe in hybridisation buffer $(30 \mu$ l per slide) was then applied with probe concentration ranging from $0.5 \mathrm{ng} / \mu \mathrm{l}$ to $10 \mathrm{ng} / \mu \mathrm{l}$, and the sections were hybridised overnight at $37^{\circ} \mathrm{C}$ or $48^{\circ} \mathrm{C}$ in a humid chamber.

After hybridisation sections were washed in decreasing concentrations of SSC; $4 \mathrm{x}, 2 \mathrm{x}, 1 \mathrm{x}$, and $0.5 \mathrm{x}$ for 15 minutes at each concentration of SSC. Posthybridisation washing was performed at the same temperature as the prehybridisation. Sections were then washed in $0 \cdot 05 \mathrm{M}$ TRIS-HCl buffer ( $\mathrm{pH} 7 \cdot 6)$ containing $0 \cdot 15 \mathrm{M}$ sodium chloride (TBS) and normal sheep serum (20\%) in TBS applied for 15-30 minutes to block non-specific antibody binding. Alkaline phosphatase conjugated sheep antidigoxigenin antibody (Boehringer) diluted 1 in 200 in TBS containing 5\% normal human serum was applied for four hours. Unbound antibody was removed by washing slides in TBS and showing sites of bound alkaline phosphatase. The alkaline phosphatase incubating medium consisted of $10 \mathrm{ml} 0.05 \mathrm{M}$ TRIS-HCl buffer ( $\mathrm{pH} \mathrm{9}$ ), $10 \mathrm{mg}$ nitroblue tetrazolium (Sigma), $6 \mathrm{mg}$ sodium azide, $10 \mathrm{mg}$ magnesium chloride, $3 \mathrm{mg}$ levamisole (Sigma) and $4 \mathrm{mg}$ bromo-chloroindolyl-phosphate (Sigma). Slides were incubated at $37^{\circ} \mathrm{C}$ overnight (for about 16-18 hours), then washed in water, optionally counterstained, air dried and mounted in glycerine jelly.

Sections hybridised in the absence of probe, sections subject to ribonuclease digestion (sections were digested for three hours at $37^{\circ} \mathrm{C}$ in a solution consisting of ribonuclease A $2 \mathrm{mg} / \mathrm{ml}$, type II-A Sigma, and ribonuclease T1 10000 Units/ml, Sigma, both enzymes dissolved in

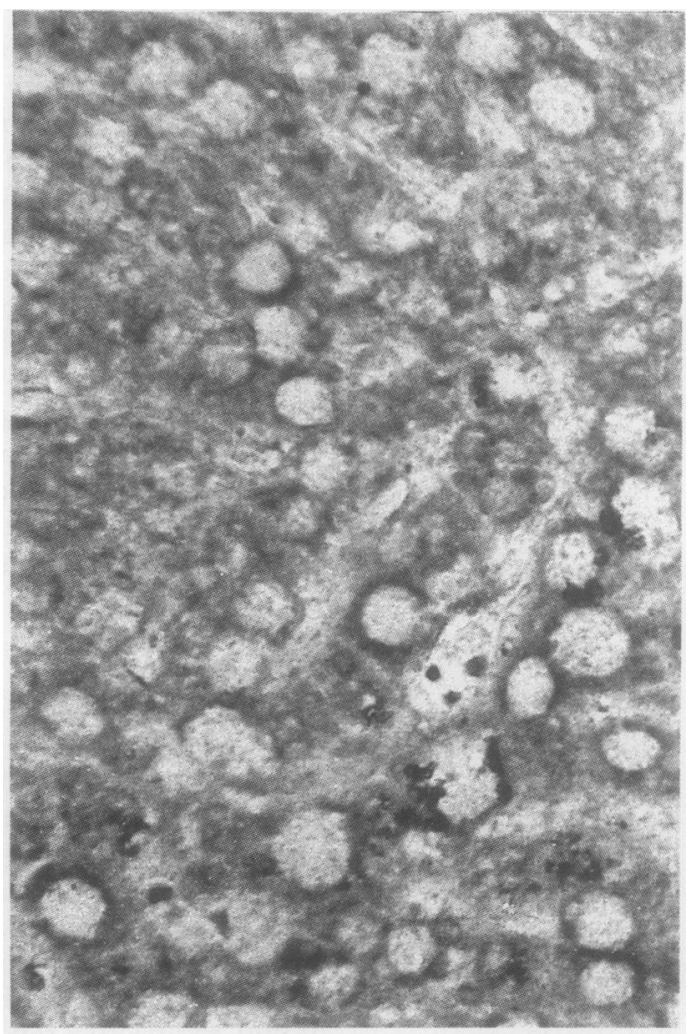

Figure 1 In situ hybridisation with a digoxigenin labelled oligonucleotide probe identifies albumin mRNA in the cytoplasm of hepatocytes of a normal liver biopsy specimen. 
Figure 2 There is no background staining in on a normal liver biopsy specimen in the absence of digoxigenin labelled probe (haematoxylin counterstain) hepatocytes when in situ hybridisation is performed

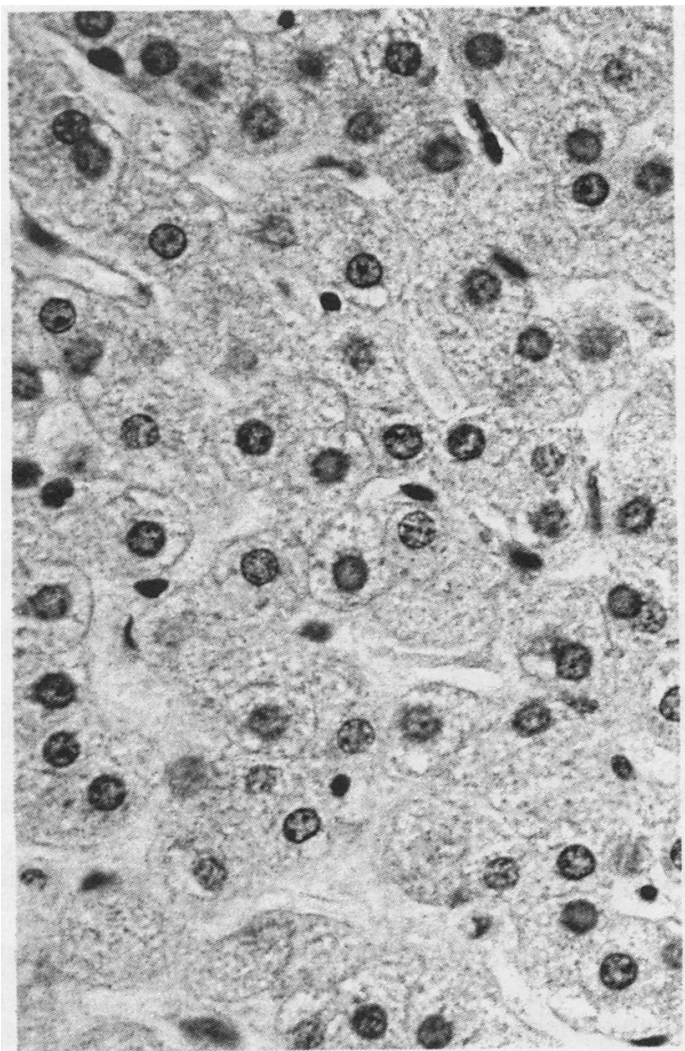

distilled water) before hybridisation, and sections of normal pancreas were used as controls.

\section{Results}

A positive hybridisation signal was obtained in the hepatocytes of normal liver biopsy specimens after hybridisation with the digoxigenin labelled oligonucleotide probe. The signal was present in all hepatocytes and

Figure 3 In situ hybridisation with a digoxigenin labelled probe shows the presence of albumin $m R N A$ in the tumour cells of $a$ hepatocellular carcinoma.

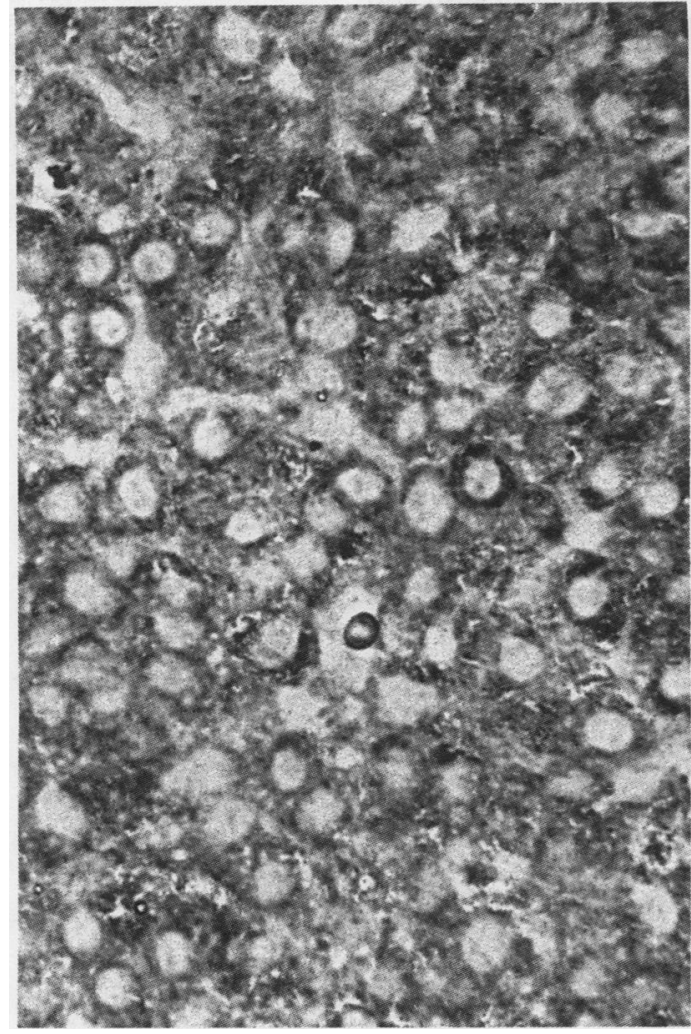

there was no apparent qualitative intra-acinar variation in the intensity of the positive signal. The positive signal was only observed in the cytoplasm of hepatocytes; there was no hybridisation signal present in hepatocyte nuclei, biliary epithelium, Kupffer cells or vascular endothelium (fig 1 ).

No signal was observed in hepatocytes (fig 2) when hybridisation was performed in the absence of labelled probe or when sections of normal pancreas were used in place of liver sections. Similarly, pretreatment of liver sections with ribonuclease produced a sharp decrease in the hybridisation signal in hepatocytes. The oligonucleotide probe also recognised a band of the appropriate molecular weight for human albumin mRNA when used in northern blot analysis of normal human liver mRNA (Leishman AI, Melvin WT, unpublished observations).

Proteolytic enzyme digestion with proteinase $\mathrm{K}$ was required to obtain optimal detection of albumin mRNA. A short time (10-20 minutes) of enzyme digestion provided maximal hybridisation signal and minimal background. Longer times of exposure to proteinase $\mathbf{K}$ resulted in overdigestion of the tissue and no proteolytic enzyme digestion resulted in a poor hybridisation signal. Overnight hybridisation at $48^{\circ} \mathrm{C}$ was better than hybridisation at $37^{\circ} \mathrm{C}$.

A positive signal for albumin mRNA was detected in the cytoplasm of malignant hepatocytes of biopsy specimens from hepatocellular carcinomas (fig 3). Nine of the 12 specimens of hepatocellular carcinomas gave a positive signal for albumin mRNA; three tumours gave no hybridisation signal. There were no clinically relevant histopathological differences between the tumours which showed positive staining for albumin mRNA and those that were negative. In biopsy specimens which gave a positive hybridisation signal for albumin mRNA the staining seemed to be present in most or all tumour cells and this was generally of an equal intensity in all positive cells. The intensity of the hybridisation signal in tumour cells was generally equal to or slightly less than the signal in adjacent non-neoplastic liver cells.

\section{Discussion}

We have studied the localisation and distribution of albumin mRNA in normal liver biopsy specimens and those from hepatocellular carcinomas using a synthetic oligonucleotide probe labelled at its $3^{\prime}$ end with digoxigenin 11dUTP. Albumin is the major serum transport protein synthesised by the liver and albumin mRNA was detected in all hepatocytes of formalin fixed, wax embedded normal liver biopsy specimens with no apparent intraacinar variation in the intensity of the hybridisation signal. A previous immunocytochemical study showed that immunoreactive albumin positive hepatocytes were present throughout the liver acinus without a preferential localisation to any particular zone. ${ }^{14}$

There was no background staining of the liver in the absence of digoxigenin labelled 
probe and this contrasts with the potential noticeable background staining of the liver which could occur when using biotin labelled probes due to the high concentration of endogenous biotin. Digoxigenin therefore seems to be the label of choice for non-radioactive in situ hybridisation studies of the liver.

Proteolytic enzyme digestion of the formalin fixed, wax embedded sections of liver was necessary to obtain the optimal hybridisation signal as has previously been reported for fixed wax embedded sections, ${ }^{15}$ and a short incubation with proteinase $K$ gave the best results. Prolonged exposure of the liver sections to proteinase $K$ resulted in overdigestion of the liver sections with loss of the hybridisation signal and poor tissue morphology, and omission of proteinase $\mathrm{K}$ digestion resulted in a poor hybridisation signal. Performing the hybridisation at $48^{\circ} \mathrm{C}$ gave better results than hybridisation at $37^{\circ} \mathrm{C}$ and this is consistent with a recent study of the in situ detection of pro-opiomelanocortin mRNA using oligonucleotide probes; this found improved hybridisation at higher hybridisation temperature, presumably due to better diffusion and penetration of the oligonucleotide probe. ${ }^{16}$

The liver is the only organ which synthesises albumin and albumin has been proposed as a marker of hepatocellular carcinoma ${ }^{17}$ as immunoreactive albumin has been identified in most hepatocellular carcinomas. ${ }^{18}$ The detection of albumin by immunocytochemistry, however, often gives results which are difficult to interpret because of excessive background staining due to albumin present in serum; moreover, damaged cells can absorb albumin from serum, giving false positive results. Detection of albumin mRNA by in situ hybridisation does not have these problems and the identification of albumin mRNA in hepatocellular carcinoma could be a useful and novel confirmatory diagnostic marker of hepatocellular carcinoma because the in situ hybridisation of albumin mRNA using an oligonucleotide probe can readily be performed on formalin fixed, wax embedded liver biopsy specimens.
This work was supported by a grant from Grampian Health Board.

1 Polak JM, McGee JO'D, eds. In situ hybridisation. Oxford: Oxford University Press, 1990.

2 Dirks RW, Van Gijlswijk RPM, Tullis RH, et al. Simultaneous detection of different mRNA sequences coding for neuropeptide hormones by double in situ hybridization using FITC- and biotin-labelled oligonybridization using FITC- and biotin-labelled

3 Jirikowski GF, Ramalho-Ortigao JF, Lindl T, Seliger H. Immunocytochemistry of 5-bromo-2'-deoxyuridine labelled oligonucleotide probes. Histochemistry 1989; 91:51-3.

4 Herrington CS, Burns J, Graham AK, Evans M, McGee JO'D. Interphase cytogenetics using biotin and digoxigenin labelled probes: relative sensitivity of both receptor molecules for detection of HPV16 in CaSki cells. J Clin Pathol 1989;42:592-600.

5 Farquharson M, Harvie R, McNicol AM. Detection of messenger RNA using a digoxigenin end labelled messenger RNA using a digoxigenin end labelled

6 Morimoto H, Monden T, Shimano T, et al. Use of sulfonated probes for in situ detection of amylase mRNA in formalin-fixed paraffin sections of human pancreas and in formalin-fixed paraffin sections of human pan

7 Grody WW, Cheng L, Lewin KJ. In situ viral DNA hybridisation in diagnostic surgical pathology. Hum Pathol 1987;18:535-43.

8 Lloyd RV, Jin L, Fields K. Detection of chromogranins A and $B$ in endocrine tissues with radioactive and biotinylated oligonucleotide probes. Am J Surg Pathol 1990;14:35-43.

9 Akhtar N, Ruprai A, Pringle JH, Lauder I, Durrant STS. In situ hybridisation detection of light chain mRNA in routine bone marrow trephines from patients with suspected myeloma. Br J Haematol 1989;73:296-301.

10 Samoszuk M, Nansen L. Detection of interleukin-5 messenger RNA in Reed-Sternberg cells of Hodgkin's disease with eosinophilia. Blood 1990;75:13-6.

11 Lewis ME, Krause RG, Roberts-Lewis JM. Recent developments in the use of synthetic oligonucleotides for in situ hybridisation histochemistry. Synapse 1988;2: 308-16.

12 Dugaiczyk A, Law SW, Dennison OE. Nucleotide sequence and the encoded amino acids of human serum albumin. Proc Natl Acad Sci USA 1982;79:71-5.

13 Beaune PH, Umbenhauer DR, Bork RW, Lloyds RS, Guengerich FP. Isolation and sequence determination of a Guengerich FP. Isolation and sequence determination of a
cDNA clone related to cytochrome $P-450$ nifedipine cDNA clone related to cytochrome P-450 nifed
oxidase. Proc Natl Acad Sci USA 1986;83:8064-8.

14 Feldmann G, Penaud-Laurencin J, Crassous J, Benhamou JP. Albumin synthesis by human liver cells: Its morphological demonstration. Gastroenterology 1972;63: $1036-48$

5 Larsson LI. In situ hybridisation of messenger RNA sequences. Histochem $J$ 1989;21:435-40.

16 Larsson LI, Hougaard DM. Optimization of non-radioactive in situ hybridisation: image analysis of varying pretreatments, hybridisation and probe labelling condipretreatments, hybridisation and probe
tions. Histochemistry 1990;93:347-54.

17 Anthony PP. Liver tumours: an update. In: Anthony PP, MacSween RNM, eds. Recent advances in histopathology. MacSween RNM, eds. Recent advances in histopath

18 Kojiro M, Kawano Y, Isomura T, Nakashima T. Distribution of albumin- and/or $\alpha$-fetoprotein positive cells in hepatocellular carcinoma. Lab Invest 1981;44:221-6. 